Island Studies Journal, Vol. 11, No. 1, 2016, pp. 227-244

\title{
Innovation in island ecotourism in different contexts: Yakushima (Japan) and Tahiti and its Islands
}

Anne-Marie d'Hauteserre

University of Waikato, New Zealand

adhautes@waikato.ac.nz

and

Carolin Funck

Hiroshima University, Higashi-Hiroshima, Japan

funckc@hiroshima-u.ac.jp

\begin{abstract}
This article examines whether the future of tourism in island destinations lies in more and continued innovation on the part of all stakeholders so tourists will consider the extra expense of travelling a worthwhile investment. Islands have long been icons as tourism destinations. However, established destination images can cause a lack in adaptability to changing markets. Though located in different parts of the world and seeking different markets most island destinations would benefit from innovative strategies and products to enhance their attractiveness to high yield visitors. The article uses two examples to analyse the innovative forms that have been adopted in island destinations in the hope they could become models or encourage imitation by other destinations. Two aspects of innovation are discussed. New imaginary can creatively and innovatively (re-)imagine representations; sustainability could be an important innovative pursuit, which requires new narratives for continued tourism growth. These concepts are applied next to the island of Yakushima in Japan and Tahiti and its Islands to determine the main innovative elements used or required to jumpstart the attractiveness of island destinations, though it is recognized that implementation is complex.
\end{abstract}

Keywords: ecotourism, image, innovation, island tourism, Tahiti, Yakushima

(C) 2016 - Institute of Island Studies, University of Prince Edward Island, Canada

\section{Introduction}

Many factors support tourism as a political and economic project in numerous different destinations. As residents of major markets have become more aware of the carbon imprint of long distance travel, remote destinations like some islands have been forced to carefully consider their attractiveness. This imprint may discourage some travellers and may interfere with destinations' efforts at maintaining a presence on main markets (Yea, 2002). It means that tourism projects must be innovatively constructed as true magnets if they want numbers of visitors to keep supporting their tourism activities or to move visitors to destinations considered remote (e.g. Tahiti). On the other hand, islands have the advantage of clearly defined destinations in that it is easier to create a coherent image which, however, needs to be adjusted to changing trends in the volatile tourism market. Islands also can draw on singular histories and culture (Hay, 2013, p. 212). 
Several factors are important for an economy to remain vibrant, whatever the sector: skilled labour, infrastructure and innovative capacity (Schumpeter, 1975). Among them, innovation is crucial for improving competitiveness, especially for long term growth since globalization has made the other two factors of production ubiquitously accessible. This article examines whether the future of tourism in island destinations lies in more and continued innovation on the part of all stakeholders so tourists will consider the extra expense of travelling (to those located far away) a worthwhile investment (Farran \& Forsyth, 2013). The aim is to examine some of the main elements of innovation used or required to jumpstart the attractiveness of island destinations, on the basis of two examples in different locations and seeking different kinds of markets, though it is recognized that implementation is complex. Tourism has become a business environment that requires flexible interaction with a fast-changing reality.

In order to question whether and how innovation can lead to greater or to renewed attractiveness of island destinations, the article first investigates innovation in tourism and discusses how a new imaginary ${ }^{1}$ can creatively and innovatively (re-)imagine representations. The article then examines how sustainability could be an important innovative pursuit, which requires new innovative narratives for stable tourism growth. These concepts are applied next to the island of Yakushima in Japan and Tahiti and its islands to determine how they have (in Yakushima) or might (Tahiti) help improve tourist arrival numbers and yield. Our examples have the advantage of hindsight as well as relevance for their future and that of other destinations (Beeton, 2005, p. 38) as they can provide clues for wider applicability, through an “... in-depth understanding of a contemporary phenomenon in its real-life context, using multiple sources of evidence" (Beeton, 2005, p. 42). Grounded theory (Bryant \& Charmaz, 2007) rendered the use of specific examples an important method of research because theory could be built from them.

The methodology is qualitative, based on semi-structured interviews of local entrepreneurs, members of government responsible for tourism policy, members of tourism bureaux and tourism agencies as well as non-formal interviews of local residents and surveys of tourists. Tourism statistics and material published by public and private institutions for each location over a period of several years were also collected and analyzed. In Yakushima, research was conducted in 2005, 2009, 2010, 2011 and 2014. In Tahiti and its Islands, the research was carried out during regular visits of two to six weeks every two to three years since 1993. The emphasis is on a longitudinal analysis of the development of tourism within each local social context (Dredge \& Hales, 2012, p. 418) to determine innovative aspects used or those that might improve the situation and to demonstrate their applicability in other destinations. The domestic entrepreneurs and public entities of Yakushima Island in Japan are combating competition for domestic consumers. Tahiti and its Islands need to implement innovative features to attract more international visitors who have shunned the destination for several years. Although situated in different contexts they share similar issues of image creation and adaptation and the constant need for innovation.

\footnotetext{
${ }^{1}$ Imaginary refers to the 'creation or production of worlds' that produce a sense of authority, domesticating other spaces or articulating spaces of difference; spaces of constructed (in)visibility installed by dominant regimes of power, practice and representation (Gregory et al., 2009). Imagery is just one aspect of this 'construction'.
} 
Innovation in island ecotourism

\section{Role of innovation in boosting touristic attractiveness}

\section{Innovating in tourism}

Innovation is defined here as the first introduction of a new product or a new variation in the market or new organizational structures and procedures, as part/result of a process of discovery, development and commercialization (OECD, 2001; Sternberg, 2009). It is more than novelty. Innovation also differs from invention because of this intent for commercial use. Innovation thus meets (or needs to meet) a number of requirements such as competitiveness, market expansion and/or customer satisfaction since innovation for its own sake rarely occurs. Innovation takes place within the broad economic and social context at all scales. The tourism and travel context too is constantly changing, imposing novel conditions to exploit for a profit (Hjalager, 2002, 2009). The risks and uncertainties of outright innovative solutions sometimes have them shunned in favour of standardized ones. These, however, rarely respond to the new market demands (Moscardo, 2008). Innovation can be home grown; it can also use the local capacity to adopt and adapt knowledge produced elsewhere (Cooke \& de Laurentis, 2010).

Governments that depend on tourism growth can actively encourage tourism entrepreneurs to create innovations to remain competitive (Hall, 2011). Entrepreneurs are considered an important link in the chain between scientific invention and industrial innovation especially today where sustainability principles require a new approach. Tourism is essentially a service activity so organizational or process innovations are more common than product innovations (Hall \& Williams, 2008; Nordin, 2003). Past examples of innovative tourism entrepreneurs include the founder of "Club Med@", the creator of bungee jumping or producers of wildlife experiences.

Tourist spaces are not pre-existing, available for development and static. They are invented stages to seduce tourists so they can be re-constructed innovatively even if structuring or restructuring of these stages depends on processes that construct what is socially 'acceptable' or what is considered socially relevant, visible or visitable (Dicks, 2003). Creating tourist spaces can be considered innovative, especially if they offer something 'different' to the market solicited (Power, 2010). Tourism is the complex interaction of extremely diversified activities many of which are considered location bound, at least in the short term, requiring their clients to move to them. In a world which is always suspended in between, and structured around flows or fluxes of people, images, information and money, place needs to be marked by openness and dynamic change rather than boundedness and static permanence.

Tourism entrepreneurs and investors continually seek new markets to expand profits and need innovation to develop products and fashions that should enchant us. Tourism and its products operate under the structural conditions of dynamic consumer development as well as a seemingly endless supply and variety. The objective, for both sellers and buyers of differentiation, is to create experiences that appear to be unique (Power, 2010). Products and places that cannot deliver at least a semblance of difference become ignored. Islands, which have long lured tourists through a combination of physical separateness, cultural difference, attractive environment, an image of hospitality and last but not least sun and sea, nowadays 
face blurred place identities as pleasure islands (Lockhardt, 1997, pp. 5-6). In this context, innovation and learning have since been central tenets of the development of differentiation.

\section{Innovation and the imaginary}

The social imaginaries of the main tourism markets create regulated (pre-packaged) tourism destinations (Mansvelt, 2005). In eco/cultural tourism, remote and exotic places become displays for the entertainment of visitors preoccupied first and foremost with the spectacle (Debord, 1992; Yea, 2002). Reality at the destination is then made to correspond with the marketing image, rather than remain different or opposite. Tourism, as one area of capital investment, imposes taxonomic control about difference but a difference that disregards local reality and its ability to offer innovative products: it emphasizes simulacra and encourages listing, knowing, possessing, rather than appreciation on the part of visitors through close encounters (d'Hauteserre, 2006, 2010; Olsen, 2008). Innovation could reverse this situation, if it is introduced by those who provide this 'difference' in areas peripheral to major global markets as they engage, transform and overthrow domination of tourism by core countries and their investors (Nand, 2013).

Products need to be innovatively creative to capture the imagination of potential tourists as they themselves often take an active role in assembling the product (Prahalad \& Ramaswarmy, 2004; Tukker \& Tischner, 2006). The imaginary (of both producers and consumers) can be harnessed for the creation of destinations and their attractions. In tourism, however, the imaginary of the centers, and thus that of tourists, has controlled its development and dissemination in the peripheral destinations. Tourist imagery and the myths thus constructed determine what places become destinations more than the actual resources available at that destination (Amoamo, 2011; Dicks, 2003), hence the importance of how the imagery is created and on what basis (Nand, 2013). This situation is changing somewhat under the influence of the growth of tourism from non-western areas because those tourists do not necessarily have the same imaginary as westerners.

Various answers have been offered in order to take into account the local environment and its residents and the relationships they wish to establish between the two. Tourism development needs to mobilise the creative capacity of its stakeholders through an innovative imaginary to better exploit its assets for local benefits. One way might be through the use of specificities of the local environment and the cultural heritage from which they originate. The new images would reflect the specific identity (and thus difference) of their place. Indigenous people could redefine 'exoticism' by presenting their cultural and environmental knowledge, instead of the center, so their exotic difference is no longer defined as 'primitive' (d'Hauteserre, 2010; Olsen, 2008; Zeppel, 2006). These images would remold the expectations and emotions of future visitors.

In the case of island destinations, the competition itself has already moved away from the balneal mono-product (the three or four Ss) to transform it into an irresistible magnet for different kinds of purposes, including responding to demands for sustainability. Bali is an excellent example that could inspire Tahiti: they have had to surmount terrorist acts, yet visitors have returned. Jersey has been analyzed as a successful case of complex branding that includes place as well as goods and is imbedded in several traditional industries on the island (Johnson, 2012). Such representations, together with efforts for sustainable development, will beam these magnetic products to tourists who can discard past icons on which previous promotion relied. 


\section{Innovation, sustainability and ecotourism}

The sustainability paradigm was the fruit of creative/innovative imaginary of those who proposed it originally, even if we still need to convince large numbers of its significance for the future. It would be an innovative policy in French Polynesia where neo-liberal economics have dominated until now. Sustainable tourism can be considered a quest for a tourism that would benefit the local population (rather than outside interests) allowing not only the preservation of local values and institutions, but also the potential to negotiate adjustments to contemporary moving realities. The costs to the local community would also be shared by all investors. Since sustainability seeks to redefine interaction between humans and the environment in a complex and dynamic context, the adoption of ecotourism could 'provide an opportunity to bridge the gap between natural resource conservation and community development' (Lai \& Nepal, 2006, p. 119) which would be a new form of engagement in Tahiti. Liu (2003, p. 459), however, notes that the use of sustainability principles in tourism is "patchy, disjointed and often flawed with false assumptions and arguments".

Creating sustainable development indicates a shift in narratives or a turn to new innovative ones in the imaginary of tourism development to provide more benefits to the local population. Community participation has been heralded as an important tool in the struggle against inequalities (Higgins-Desbiolles, 2007; Mowforth \& Munt, 2015). It would mean adopting local knowledge systems and community level actions and using resources local people currently control. Policies and authorities, rooted in broader political concerns about social justice and active local (including Indigenous or minority) participation, need to encourage supportive cooperation. Empowerment involves local people holding the will, resources and opportunity to make decisions (Fennell, 2003, p. 159). Training or education is also important to enable residents to cope with the pressures of tourism and with disappointing behaviours of tourists.

Ecotourism has been considered a form of sustainable tourism that supports a large degree of local involvement, develops strong linkages between the various enterprises and their promotion, and can reduce leakages through increased financial returns to local operators and to local governments (Fennell, 2003). Ecotourism, in spite of a lack of definitional consensus, originally described visits to natural areas but numerous critics felt it was too restrictive. Other attributes have been added over time such as conservation efforts, culture appreciation, education, and a growing sensitivity to community based initiatives to benefit local people (Honey, 1999; Stronza, 2005; Tipa \& Nelson, 2008). An emphasis on culture is based on the idea that creative, cultural and innovative industries are drivers of competitiveness and economic improvement (Florida, 2002; Power \& Scott, 2004; Schmid, 2009). The cultural products offered though "need to use local customs, traditions and traditional knowledge ... while being protected using appropriate intellectual property mechanisms" (Nand, 2013, p. 95).

Unfortunately, ecotourism has not always been a panacea due to irresponsible practices by some of its providers and consumers (Russell and Wallace, 2004). Ecotourism is not either a solution for all economic and social needs faced by peripheral areas. Ecotourism is seen, 
though, as one main way for Indigenous groups to conserve and benefit from biodiversity and their traditional culture (Stronza, 2005), which would be an innovation in Tahiti, relative to top-down foreign development. Zeppel (2003, p. 56) defines Indigenous ecotourism as "nature based attractions or tours owned by Indigenous people, and also Indigenous interpretation of the natural and cultural environment including wildlife", an alternative to extractive land uses. Consumptive activities like fishing and hunting are not considered 'true' ecotourism (Honey, 1999) but are often complementary. It is community based tourism that benefits local people by providing some income for local community development (Fennell, 2003; Notzke, 2006), much needed in Tahiti or on the peripheral islands of Japan.

Ecotourism also needs to be adjusted to regional and local conditions. In a highly developed country like Japan, locations with a high potential for ecotourism are scattered around the less-developed periphery, on the islands of Ogasawara or Okinawa, in Hokkaido and other remote parts of the country. However, the definition used in Japan has been expanded to include managed ecosystems like satoyama ${ }^{2}$. In contrast to "green tourism", a term which in Japan has been applied to rural or agro-tourism (Funck \& Cooper, 2013), the structure of development differs, as ecotourism is often initiated by scientists, environment protection groups and urban inhabitants relocating to areas of outstanding natural quality.

\section{The introduction of ecotourism in Japan: the case of Yakushima island}

\section{Tourism and ecotourism in Japan}

Japan has a well-established tourism market and tourism industry. However, although international tourism to Japan has increased in the $21^{\text {st }}$ century due to economic growth in nearby Asian countries, most locations still rely mainly on domestic tourists. The once stable and sheltered domestic market with a strong core area of package tours and school trips has given way to a wide array of consumer fancies and fierce competition with an ever wider choice of foreign destinations. This, on the other hand, has created room for new forms like ecotourism, green tourism, ${ }^{3}$ health tourism, heritage tourism or, based on the consumed experience, food, art, film and 'contents tourism'. "Grouped together as "new tourism" by the Japanese Tourism Agency, these forms emphasize encounters with local culture and nature and therefore raise high expectations as innovative tools to revive local economies (Tokushû: "nyû tsûrizumu" no shijô kankiryoku 2008, p. 33).

The introduction of ecotourism can be classified as an innovation at the national as well as the local level. On the local level, nature fans looking for a way to earn their living in a natural location in Japan developed Japanese style eco-tours. At the national level, the Law for the Promotion of Ecotourism introduced a new definition with strong cultural elements and the possibility to designate and protect ecotourism resources at the local level. NGOs and other civil society organisations have played an important role in the promotion of integrated conservation and development projects in ecotourism worldwide (Butcher, 2007, p.8). In Japan, organizations centred around ecotourism include the Ogasawara Whale Watching

\footnotetext{
${ }^{2}$ Satoyama refers to rural Japanese landscape, especially the secondary grasslands and woodlands traditionally managed by village communities (Funck \& Cooper, 2013, p.192).

${ }^{3}$ In the Japanese context, green tourism refers to rural or agro-tourism and includes visits to rural villages, agricultural experiences and the consumption of agricultural goods (Arahi, 2008).

${ }^{4}$ Contents tourism refers to tourism based on the contents of media, mainly manga, animated movies, TV-shows and computer games.
} 
Association, founded in 1989, which introduced regulations for correct whale watching tours as early as 1994 (Nakai, 2002) $^{5}$. Another forerunner in ecotourism is the Iriomote Ecotourism Society in Okinawa. It was established by local tourism entrepreneurs, transport industries and citizen groups in 1996 to promote ecotourism as a new form of tourism development (Maita et al., 2010, p. 40).

After almost ten years of local activities the Japan Ecotourism Society was founded nationwide in 1998 and gained recognition as an NPO (non-profit organization) in 2003. Its definition of ecotourism emphasizes the balance between three elements: preservation of regional nature, history and culture, promotion of tourism and regional vitalization. Emphasis is more on tourism than on the preservation of natural resources. In the policy sector, the Ministry of the Environment started the promotion of ecotourism in 2003 with a commission to discuss benefits and problems of ecotourism. A law to promote ecotourism was then enacted in 2008. It defined ecotourism as "an activity where tourists receive explanations and advice from guides knowledgeable about natural tourism resources and come in touch with natural tourism resources in a way that considers the conservation of these resources" (Ministry of the Environment, 2011, p. 5). To this definition, four principles were added: conservation of natural tourism resources, tourism promotion, economic and social development and environmental education. Under the law, communities can set up councils for the promotion of ecotourism, draw up basic plans to be certified by the government and designate specific natural tourism resources. They can then set rules and restrictions for the use of these resources.

The contents of the law and the underlying concept of ecotourism include some innovative elements. The Japanese concept has been adapted to the context of a densely populated country with a highly developed tourism market and, through the emphasis on environmental education, opened up possibilities to promote ecotourism in areas with a long history of human and nature interaction. As with Natura 2000, the European system of protected areas to preserve and reconstruct representative habitats of European nature (Wurzel, 2008), it acknowledges the fact that most habitats nowadays have been formed and transformed by human interaction. On the national level, the possibility to designate resources and restrict their use is also an important innovation, as municipalities in Japan have very few choices to set their own rules on landscape preservation or building regulations.

\section{Ecotourism development in Yakushima}

In a densely inhabited country like Japan, all types of nature preservation districts play an important role as ecotourism resources. Since Japan joined the world heritage convention in 1992, natural world heritage registration has become the most important brand name for ecotourism. Yakushima Island in Kagoshima Prefecture was the first natural world heritage to be registered. Since its registration in 1993, it has developed into one of Japan's most famous ecotourism locations.

\footnotetext{
${ }^{5}$ The Ogasawara island chain stretches up to $1000 \mathrm{~km}$ south of Tokyo and can only reached by boat which requires 24 hours to the more remote islands.
} 
Located south of Kyushu Island, Yakushima displays rich and distinct flora changes from subtropical along the coastline to alpine around its $2000 \mathrm{~m}$ high mountain range, which receives up to $10,000 \mathrm{~mm}$ of rain per year. It also features indigenous deer and macaques. Nevertheless, the singular cedar trees said to be several thousand years of age attract the bulk of tourists. The strenuous ten-hour round trip walk to jomon sugi, a cedar presumably dating back several thousand years, has become an object of pilgrimage undertaken by more than 92.000 persons in 2008. Visitor numbers since fell to 74.402 in 2014 but still exceeded 500 per day on several occasions ${ }^{6}$. Hiking in other areas, especially in two national park recreation areas equipped with easy hiking courses, is also popular. On the other hand, marine based tourism like diving only plays a minor role.

Yakushima's forests have been logged for their precious cedar wood until the early 1980s. Tourism development started in the 1970s, when two forest areas within the designated National Park were equipped with access roads, parking lots, hiking courses and signs explaining the nature of Yakushima. Visitor arrivals on the island grew from 46,000 in 1969 to 122.000 in 1988 and to a maximum of 406.000 in 2007; numbers have fallen since then to 299.744 in $2013^{7}$. Although transport options have expanded, arrivals are still restricted by access possibilities. Access is available by ferry, high-speed boat (two hours from Kagoshima City) and plane ${ }^{8}$. However, except for the ferry, all options are expensive and often cancelled due to weather conditions. About 160 accommodation facilities, predominately small-scale pensions and a few resort hotels, cater for tourists (Kanetaka \& Funck, 2011).

Yakushima's nature attracts not only tourists, but also new inhabitants. The number of residents has stabilized since 1993, a rare phenomenon among remote Japanese islands which tend to loose inhabitants constantly. Immigrants make a living as eco-tour guides or operators of accommodation and restaurants; some of them simply enjoy retirement life. The first two guide groups, established in 1989 and 1993, consist almost completely of new inhabitants with some kind of education in ecology or long experience with outdoor sports. It is estimated that today about 180 guides are active on the island.

The concept of tours to natural areas guided by a professional thus was introduced to remote island locations by "outsiders" and has since been developed to offer a wide range of products like healing tours. According to Shibazaki (2005, p. 39), about $20 \%$ of the workforce of Yakushima worked in tourism related industries in 1999, with guides and accommodation forming the two main pillars. In 2009, about $22 \%$ of the workforce was engaged in the accommodation and restaurant sector ${ }^{9}$. However, due to strong seasonal fluctuation, most people working in these two sectors combine several activities. On the other hand, the possibility to set up and run one's own enterprise and to use off-seasons for travel has lured many of the immigrants to Yakushima.

In 2004, Yakushima was chosen as a model district for the promotion of ecotourism by the Ministry of the Environment. The Ecotourism Promotion Council founded within this project consists of representatives of local, regional and national administrators, as well as

\footnotetext{
${ }^{6}$ Yakushima World Heritage Conservation Centre annual data. Retrieved from https://www.env.go.jp/park/yakushima/ywhcc/np/cdata.htm

${ }^{7}$ Data from Yakushima Town. Retrieved from https://www.town.yakushima.kagoshima.jp/announce/\%E7\%B5\%B1\%E8\%A8\%88\%E3\%82\%84\%E3\%81\%8F $\% \mathrm{E} 3 \% 81 \% 97 \% \mathrm{E} 3 \% 81 \% \mathrm{BE} /$

${ }^{8}$ Flights to Kagoshima several times a day, to Osaka once per day and to Fukuoka once per day.

${ }^{9}$ Economic Census of Japan 2009.
} 
local organizations like chambers of commerce, tourism associations, fishing, agricultural and forest cooperatives. One of its projects was the introduction of a registration system for guides in 2006 to keep a minimum level of quality. 116 guides had registered by 2007; only 36 of them originally came from Yakushima. Registered guides need to have insurance, participate in courses on first aid and know nature protection laws. They must have resided in Yakushima and accumulated experience as guides for two years and publish their tour contents and fees. However, the number of registered guides sank as many guides didn't find any merit in registering (Kanetaka \& Funck 2011). It took until September 2015 to create a new registration system, which proves that careful consideration for all local stakeholders can delay necessary innovations.

Yakushima faces a series of threats as an ecotourism location. High visitor concentration during longer public holidays in May, August and September creates congestion on the mountain roads accessing forest parks and hiking trails and overuse of the beaches where sea turtles come to lay their eggs. During peak time, the most popular trail to jomon sugi is hiked by up to one thousand persons a day, whose leftovers in the toilets along the trail have to be carried out by park rangers and guides.

Counting devices at mountain trails since 1999, restrictions on access by private cars to the forest parks during holidays (2008) and the introduction of rules for the observation of sea turtles (2009) are some of the first steps in the process of managing ecotourism on Yakushima. Sea turtle observation on Nagata Beach has been promoted as a positive example of local management, where local inhabitants and an NPO cooperate - though not without conflicts to regulate access to the beach, provide lectures and guided observations (Chao Ge Ji Le Tu \& Asano 2011). There are also attempts to develop new tours including villages and their surroundings to relieve stress on the mountain environment. On the other hand, the town council of Yakushima in 2012 rejected a motion to restrict the number of daily visitors to jomon sugi; the problem even became a point of contest in mayoral elections in November the same year (Asahi Shinbun, (2011, June 22; October 26). While Nagata Beach could be protected due to a strong local community and scientific input from an NPO, jomon sugi has become a symbol of a perceived dilemma between tourism and nature conservation. The innovative possibility created by the Law for the Promotion of Ecotourism to define and protect resources locally thus can have very different outcomes even within the same island.

If we compare the national context with local reality, we can see that initiatives by individual entrepreneurs let to the establishment of eco-tours and guide businesses in peripheral destinations that later became reflected in the Law for the Promotion of Ecotourism, where ecotourism is clearly defined as a guided, educational activity. Such innovations have maintained the appeal of Yakushima so that tourism has continued to benefit the local area. On the other hand, the extension of ecotourism to include local cultural resources does not seem to appeal to tourists in destinations with an iconic natural resource. Finally, local management of resources, once approved by national law in principle, sometimes depends on actors and conditions on a level even more local than the smallest administrative unit, the municipality. Although it has been frequently remarked that, in Japan, the central government is the dominant player in planning and space management (Sorensen \& Funck 2007, p. 7), 
innovations on the national level draw from experiences on the local, while it might prove difficult to disseminate innovations from the national to the local levels.

\section{Tahiti and its Islands seeking to appeal to international tourists}

\section{The present situation}

Arrivals have dropped for several years in a row from a high of 220,000 in 2005 to just fewer than 154,000 in 2011. The slight increase since 2012 does not signal a major positive reversal. Have Tahiti and its Islands lost their appeal? The territory had targeted a wealthy, niche market for which it believed it had the image, the landscapes and the infrastructure. The local government maintains a (misplaced) belief that the territory has an irresistible appeal for tourists. What enticed Gauguin must have lost the power to seduce as the lagoons lose their crystal transparency and seashores are cemented. Other island nations in more than just tropical locations can now compete; but their pristine white sand beaches are only one focus. Distance for Tahiti and its Islands has always been a major challenge so numbers of visitors will never be large, but they need not continue to decline. The French state has subsidised air, sea and land links. Tahiti and its Islands thus benefit from one of the three factors necessary to attract tourists: infrastructure. However, in terms of environmental sustainability, great distance relative to present markets means a rather large carbon footprint.

Tourism seems to bring important revenues to the territory, especially when compared to other existing economic activities. It still represents a very small percentage (US $\$ 34 \mathrm{~m}$ in 2010) of the total income of the territory which is provided by the French state in the form of subsidies (US\$2 bn in 2010) (Fenua Economie, 2012). These rarely reach the people who would really need financial support. Tourism activities could provide some of them with a job in some tourism activity or in the creation of an enterprise or in activities synergistically linked to tourism. Subsidies have also raised the cost of living so many people live precariously: $28.2 \%$ of the population suffered from at least three major kinds of deprivation (DIXIT, 2010, p. 253), even though the GDP per capita for the territory was US\$15,000. It has raised the cost of investing in economic enterprises so indigenization might well be nigh impossible. The images used in tourism promotion, rather than bringing economic benefit to local people have led to objectification and marginalization of the Polynesian population (Brunel 2012; Hollinshead, 1996; Olsen, 2008).

Policies of the French and the territorial governments have facilitated investment by outside interests whose commitment was minimal because of fiscal incentives. It led to the implantation of international five star resorts that have difficulty filling (less than $50 \%$ in 2010). It has however been the excuse for charging high room rates without providing true luxury. Too often, employees are considered a cost rather than an investment, in spite of the fact that continuous innovation and improved productivity originate in the employees of the firm (SRI International, 2000). Training of staff is minimal too even though tourism's face, as a service industry, is its employees. Salaries are also higher than in Asia, restricting further the number of employees, so service is minimal. Many of these hotels await their transformation into apartments, which is the main unspoken reason they were constructed: the Radisson on a beach in Mahina has already started the process. In two cases the sacred value of land was trampled when hotels were built against the wishes of the local people who had long sought respect for those sites. Other hotels have become ruins following their closure (e.g. Hotel 
Tahara, built down a slope in Mahina, Tahiti, closed in 2000). Offering environment friendly fiscal incentives might better sustain the islands' global competitiveness (Quitzow, 2013)

One innovation was initiated by a hotel in the island of Bora Bora in the 1970s, putting bungalows over the water. Since it was not possible to monopolize such knowledge because it could not be hidden, it was quickly copied all over the tropical world, reducing Tahiti's competitive difference. It also seems to contradict somewhat the 'distance sensitivity' of innovation. Once implemented, innovation becomes a 'non-rival' good: using it does not preclude others from doing it, as the Bora Bora hotel discovered. It is also 'non-excludable': the very use of information in any productive way is bound to reveal it in part (Grossman \& Helpman, 1991, p. 15). The lack of protection of new concepts leads to free-riding, hampering the creation of trust-based rapports, as inventors are loathe to feel exploited (Hjalager, 2002; 2010). Operators are more likely to consider each other competitors rather than colleagues, even though cooperation on a shared vision is an important pre-requisite of successful innovation (Nordin, 2003; Weidenfeld, Williams \& Butler, 2010).

For small enterprises, cooperation with major local or close-by tourist attractions could support more indigenization of tourism development. A report on coastal tourism development for the SW Indian Ocean by Picard (2007) indicates that large corporate chains can help small enterprises flourish and establishing governance mechanisms would ensure such a flow-on effect, as had happened in Rangiroa (an atoll in the Tuamotu archipelago of Tahiti) with the Kia Ora resort. Many small scale projects or enterprises need customers which these large hotels can provide, if the hotels themselves cooperate by not competing with local providers and by offering a site where local operators can sell their services. Regulatory support could encourage the practice. Customers of the Kia Ora resort were informed about an orientation session held every afternoon by the various local providers of activities who then took bookings and did not have to provide the hotel with a kickback.

\section{Repairing Tahiti's market failure}

How does one bring back tourists to Tahiti and its islands, which are already well incorporated in international circuits, especially since the recent catastrophic decline of $30 \%$ over just three years while tourism in the Asia Pacific region had increased 14\% in 2010 (DIXIT, 2012)? The emphasis has been on seductiveness and tropical beaches. Tahiti and its Islands had launched 'romance tourism' but must compete with Fiji where couples can also marry, impossible legally in French Polynesia until 2012. These tourists tend to turn toward each other rather than spending to discover/consume the surrounding world (Fenua Economie, 2011). Intelligence tourism (2015) suggests tapping instead into the over 50s and even the over 65s market. French Polynesia could mobilize its creative capacity (which it has demonstrated in saving its culture: dance, for example, has most benefited from local innovative efforts) through an innovative imaginary to better exploit its assets and brand its distinctiveness. The important goal remains offering products that differentiate themselves from available alternatives (Power, 2010).

Polynesian residents can imagine the unique attractions that will transform their island into an irresistible ecotourism magnet since small enterprises can create products to satisfy 
niche consumers, as demonstrated in Yakushima. Tahiti never sought to develop mass tourism, but the government did hope to welcome 300,000 tourists by 2015 (Mission, 2000). Visiting Tahiti \& its Islands today is very expensive since most accommodation is four or five star resorts but entertainment and activities other than by or in the sea or the pool are almost nonexistent. Support for construction of smaller hotels linked to providers of ecotourism activities would offer visitors more varied ways of enjoying landscapes made famous by literature and movies. The territory has an important comparative advantage thanks to their diversified cultural and natural attributes and the high quality of its infrastructure relative to competitors in the South Pacific.

To improve its attractiveness to international tourists, French Polynesia needs to review, that is innovatively re-imagine the images/representations it beams to the world. The new representations need to address the imaginary of future potential consumers, ecotourists who are not that interested in discovering a part of France in a Pacific that is Indigenous and who want more than just a swim in turquoise colors. Its representations will need to beam new magnetic ecotourism products to post tourists who are unaware of Gauguin or Pierre Loti and vahines (exotic women). Ecotourism can provide incentives for greater conservation of biodiversity (Boley \& Green, 2012). Myth-making based on Polynesian legends or on Tahiti's unique (natural or cultural) sites represents an innovative turn from western myths of Garden of Eden and sexual licentiousness but would still provide a counter-world to residents of 'developed' countries: such as Margaret Lai's historic reconstructions on a marae (ancient Polynesian temple).

A turn towards discovery/adventure/sports tourism taking advantage of the local environment, which enables embodied participation, could replace passive lying on the beach or air-conditioned bubble touring, such as guided visits to the interior of the high islands. Indigenous guides in four-wheel drive vehicles (since no roads exist yet) to beautiful lakes and serrated valleys with lush vegetation (as in Yakushima), to hike along various trails (which do exist) to explore outside reef islands and/or scuba diving could demonstrate to visitors the interconnections between tourism, conservation, and development, which few are otherwise aware of (Mathis \& Rose, 2016).

Working hours, demographic characteristics and incomes have changed demand, forcing a new conceptualization of tourism experiences. New Zealand attracts large numbers of tourists from across the world by its originally innovative emphasis on " $100 \%$ pure adventure" in splendid natural environments that has supported local well-being. Tourism "based on adventure" and ecotourism need protected areas that, however, are rare today in French Polynesia (only 8 exist, which represent $1.8 \%$ of the total land area and $0.1 \%$ of the lagoons). There has been some improvement in environmental protection by residents but there is ample room for innovative changes (DIXIT, 2012; Fenua Economie, 2012).

Development of arts and crafts, one aspect of cultural industries (Tipa \& Nelson, 2008) but also of ecotourism can be a major contributor to tourism's local benefits when the products are unique in the souvenir market and there is a tie-in with local attractions. They have provided revenue for many families, who have been able to remain in the outer archipelagoes and they have been an outlet for surpluses of the primary products of these archipelagos. They also represent a support for Polynesian culture as traditional knowledge is pursued for innovative designs and use of local materials, black pearls and mother of pearl shells in particular. Their commodification does not automatically mean a lack of value or of cultural or social authenticity (Cohen, 2002). They can also maintain social cohesion through exchanges 
of knowledge. Visiting ecotourists can learn the cultural elements they are linked to and even participate in the making of some of these artifacts. Labeling (and/or branding) would justify the higher prices of local products compared to Asian imports.

Tourism activities could group themselves as in Waikiki (Hawaii) which caters to several million visitors per year, leaving much space to other activities (see also Nordin, 2003; Weidenfeld, Williams \& Butler, 2010). It would also facilitate cooperation between entrepreneurs, one of the key factors mentioned earlier. In Tahiti (the main island) but also in its other islands, hotels have been implanted separately, some of them far removed from each other and from service centers (e.g. independent food providers) or other attractions as they sought rare prime sea-front properties. Only two hotels are located in Papeete, the main city in Tahiti.

From the perspective of markets to explore, it would be most important to respond to the imaginary of non-western tourists in order to tap into a market that is fast developing. Korea and Japan already send tourists but China and India need to be courted. Locally created products (rather than by western interests and perspectives) have a greater chance to be acceptable to those markets since these tourists are still working out socio-economic processes most attractive to them. The reduced distance of South Pacific destinations from those outbound areas may become the South Pacific's main asset, especially relative to other competing destinations in other Oceans. Combined changes in demographic characteristics and incomes have also contributed a new market for tourism products (higher incomes and better health enable seniors to travel far and wide) that Tahiti has ignored until now because of its emphasis on 'seductiveness'.

\section{Conclusion}

Finding forms of tourism that satisfy local stakeholders and providing meaningful products and representations that would attract the desired number of visitors to island destinations depends on innovative actions to create magnetic products and beam attractive representations. Ecotourism and measures to improve sustainability, which have been introduced as innovative practices in Yakushima, could be adopted in other islands (including Tahiti and its Islands where their introduction would be very innovative). They still need to be adapted to their location so local entrepreneurs can fully benefit, as they "put tourism to work for them rather than working for tourism" (Sofield, 2003, p. 335). Competitive advantage and commercial success cannot be explained by innovation alone. A number of factors are cited as of great importance for the success of tourism development: a more open industry, cooperation by all operators with a shared vision, a strong brand, excellent infrastructure and linkages to complementary industries. However, in many areas, implementing any one of these factors would represent a major innovation, at least locally.

From the two case studies, areas that require and elements that support innovation have been identified. Elements that supported the successful introduction of ecotourism in Yakushima and the sustainable management of its ecotourism resources include a new framework on the national level, immigrants to the area from other parts of Japan who needed a new sector in the tourism industry to work in and brought experiences as guides or 
instructors, as well as technical and social solutions to concrete management problems. The latter include the use of sensors to count hikers and community management of sea turtle viewing tourism. On the other hand, the success of ecotourism has created a one-dimensional image of the islands concentrating on the iconic jomon sugi tree, so new innovations will be required to further diversification.

Creative public and private support is proposed for innovations or innovative thinking based on a better understanding of dynamic changes in the tourism market and in the practices of potential tourists as well as on better knowledge and informed use of local resources; for processes that include fair treatment of local indigenous entrepreneurs; encouraging more cooperation between tourism developers; and for promotion based on the destination's own imaginary. Many island destinations need to rethink their strategies to improve their attractiveness, in other words, they need to create innovative products and forms of marketing. This might include diversifying fossilized tourism structures: it would involve moving away from the obligatory hike to jomon sugi on Yakushima; in Tahiti it would be adopting new practices and images that would grab global attention, examples that could be followed elsewhere. An interesting aspect is the fact that in Tahiti, a new image needs to distance the island from sand and sea tourism whereas in Yakushima, a stronger emphasis on the sea, which after all is the defining feature of islands (Hay, 2013), could help to diversify tourism and relieve environmental stress on the mountain areas.

Innovative strategies and policies need to incorporate social and cultural dimensions in any form of tourism development. The development of sustainable innovative tourism is directly linked to local factors, to local narratives, to local knowledge and to local imaginary, whose implementation in 'less developed' areas would represent a major innovation. Tourism development for the benefit of the locals needs to go beyond a product-market matching approach so that local aspirations, experiences and realities guide the type and size as well as the location of destinations. Ecotourism and its products would provide more benefits locally than foreign investment in most island destinations. Yakushima, which has already adopted innovative strategies, could be a useful example for other island destinations. A better transfer of knowledge among local eco-tourism developers and innovative forms of resource management including local residents, councils and NPOs is recommended to make ecotourism more sustainable.

At the same time, tourist spaces act as stages for tourist performance. Tourist performance is shaped by the social context in which it develops. Changes in social practices in outbound markets could reduce the number of departures: charging for carbon imprint is one such deterrent; new diffidence about sunbathing requires innovative strategies to entice tourists to tropical island destinations with something other than sex tagged onto sun, sea and sand. Rebranding islands that relied on the three (or four) Ss as ecotourism destinations with eco-lodging and activities, promoted on the basis of the local culture and nature, would probably attract more visitors today than present images of seductive vahines and sunny beaches. Images need to be diversified from sites that were once iconic to promote a wider understanding of the complex relations of humans and nature on islands. Our examples demonstrate that innovation does remain one area of potential improvement of the attractiveness of destinations, especially in the case of islands that are remote, and for which visitors need to feel absolutely positive because of the greater expense required to satisfy their wanderlust. 
Innovation in island ecotourism

\section{Acknowledgements}

The research on Yakushima has been supported by the Japan Society for the Promotion of Science Grant in-Aid for Scientific Research Projects 26360065 (Carolin Funck).

\section{References}

Amoamo, M. (2011). Remoteness and myth making: tourism development on Pitcairn Island. Tourism Planning and Development, 8(1), 1-19.

Arahi, Y. (2008). The development of green tourism study in Japan. In Japanese Association for Rural Studies New developments of green tourism in rural Japan: Urban-rural exchanges as strategy to revitalize farming areas (pp. 7-42). Tokyo, Japan: Nôson Gyoson Bunka Kyôkai (in Japanese).

Beeton, S. (2005). The case study in tourism research: a multi-method case study approach. In B. Ritchie, P. Burns \& C. Palmer (Eds.), Tourism research methods, (pp. 37-48). Wallingford: CABI.

Boley, B. B. \& Green, G.T. (2015). Ecotourism and natural resource conservation: the 'potential' for a sustainable symbiotic relationship. Journal of Ecotourism, DOI: 10.1080/14724049.2015.1094080

Brunel, S. (2012). La planète disneylandisée: Pour un tourisme responsible. Auxerre, France: Sciences humaines éditions.

Bryant, A. \& Charmaz, K. (2007). The Sage Handbook of grounded theory. London: Sage.

Butcher, J. (2007). Ecotourism, NGOs and development. London: Routledge.

Chao Ge Ji Le Tu \& Asano, T. (2011). Yakushima no ekotsûrizumu o meguru shizen hogo to kankô riyô no kintô [The balance between nature conservation and tourism use in ecotourism in Yakushima]. Nihon Kenkyû (Hiroshima: Hiroshima University Faculty of Integrated Arts and Sciences Bulletin of Japanese Studies) 24, 21-44.

Cohen, E. (2002). Authenticity, equity and sustainability in tourism. Journal of Sustainable Tourism 10(4), 267-276.

Cooke, P. \& de Laurentis, C. (2010) Analysis and summaries from the seven sector chapters. In P. Cooke, C. de Laurentis, S. MacNeill \& C. Collinge (Eds.), Platforms of innovation: Dynamics of new industrial knowledge flows (pp. 251-270). Cheltenham: Edward Elgar.

Debord, G. (1992). La société du spectacle. Paris: Gallimard.

d'Hauteserre, A-M. (2010) Government policies and Indigenous tourism in New Caledonia. Asia Pacific Journal of Tourism Research, 15(3), 285-303.

d'Hauteserre, A-M. (2006). Landscapes of the tropics. In T. Terkenli \& A-M. d'Hauteserre (Eds.), Landscapes of a new cultural economy of space (pp. 149-170). Dordrecht: Springer.

Dicks, B. (2003) Culture on display: The production of contemporary visitability. Maidenhead: McGraw-Hill.

DIXIT. (2010; 2012). Revue économique, sociale et culturelle de Polynésie Française, 18 and 20. Papeete: Editions Créaprint. 
Dredge, D., \& Hales, R. (2012). Community case study research. In L. Drywer, A. Gill, A. \& N. Seetaram (Eds.), Handbook of research methods in tourism (pp. 423-437). Cheltenham: Edward Elgar.

Farran, S., \& Forsyth, M. (2013). Introduction. Pacific Studies 36(1/2), 3-13.

Fennell, D. (2003). Ecotourism: An introduction (2 ${ }^{\text {nd }}$ edn). London: Routledge.

Fenua Economie (2010; 2011; 2012). Le magazine de l'économie polynésienne, 8, 9, 10. Papeete: La Dépêche.

Florida, R. (2002). The rise of the creative class: And how it's transforming work, leisure, community and everyday life. New York: Basic Books.

Funck, C., \& Cooper, M. (2013). Japanese tourism: Spaces, places and structures. New York: Berghahn

Gregory, D., Johnson, R., Pratt, G., Watts, M.J., \& Whatmore, S. (Eds.) (2009). The dictionary of human geography. Malden MA: Wiley Blackwell.

Grossman, G. \& Helpman, E. (1991). Innovation and growth in the global economy. Cambridge MA: MIT Press.

Hall, C. M. (2011). Policy learning and policy failure in sustainable tourism governance: From first and second-order to third-order change? Journal of Sustainable Tourism, 19(4-5), 649-671.

Hall, C. M., \& Williams, A. (2008). Tourism and innovation. London: Routledge.

Hay, P. (2013). What the sea portends: a reconsideration of contested island tropes. Island Studies Journal, 8(2), 209-232.

Higgins-Desbiolles, F. (2007). Taming tourism: indigenous rights as a check to unbridled tourism. In P. M. Burns \& M. Novelli (Eds.), Tourism and politics (pp. 83-108). Oxford: Elsevier.

Hjalager, A-M. (2010). A review of innovation research in tourism. Tourism management, 31, $1-12$.

Hjalager, A-M. (2009). Cultural tourism innovation systems: the Roskilde festival. Scandinavian Journal of Hospitality and Tourism, 9(2/3), 266-287.

Hjalager, A-M. (2002). Repairing innovation defectiveness in tourism. Tourism Management, 23(5), 465-474.

Hollinshead, K. (1996). Marketing and metaphysical realism: The disidentification of Aboriginal life and traditions through tourism. In R. Butler \& T. Hinch (Eds.), Tourism and indigenous peoples (pp. 308-348). New York: International Thomson Business Press.

Honey, M. (1999). Ecotourism and sustainable development. Washington, DC: Island Press.

Johnson, H. (2012). 'Genuine Jersey': branding and authenticity in a small island culture. Island Studies Journal, 7(2), 235-258.

Kanetaka, F. \& Funck, C. (2012). The development of the tourism industry in Yakushima and its spatial characteristics. Studies in Environmental Science (Bulletin of the Graduate School of Integrated Arts and Sciences, Hiroshima University, II), 6, 65-82.

Lai, P. H. \& Nepal, S. K. (2006). Local perspectives of ecotourism development in Tawushan Nature Reserve, Taiwan. Tourism Management, 27(6), 1117-1129.

Liu, Z. (2003). Sustainable tourism development: a critique. Journal of Sustainable Tourism, 11(6), 459-475.

Lockhardt, D. G. (1997). Islands and tourism: an overview. In D.G. Lockhardt \& D. DrakakisSmith (Eds.), Island tourism: Trends and prospects (pp. 3-20). New York: Pinter. 
Makita, K. (2008). Kauntâ ni yoru riyôsha no haaku [Catching users through counters]. In A. Kobayashi, \& T. Aikô (Eds.) Riyôsha no kôdô to taiken [Visitor use and experience] (pp. 59-71). Tokyo, Japan: Kokon Shoin.

Mansvelt, J. (2005). Geographies of consumption. London: Sage.

Mathis, A. \& Rose, J. (2016). Balancing tourism, conservation, and development: a political ecology of ecotourism on the Galapagos Islands., Journal of Ecotourism, DOI: 10.1080/14724049.2015.1131283.

Ministry of the Environment. (2011). Nihon ni okeru ekotsurizumu no torikumi ni tsuite [Approaches to ecotourism in Japan]. Retrieved from http://www.env.go.jp/nature/ecotourism/try-ecotourism/env/review/1_1.html

Mission d'Evaluation et de Prospective. (2000). Rapport de prospective. Papeete: Présidence du Gouvernement de la Polynésie Française.

Moscardo, G. (2008). Sustainable tourism innovation: Challenging basic assumptions. Tourism and Hospitality Research, 8(1), 4-13.

Mowforth, M. \& Munt, I. (2015). Tourism and sustainability: Development and new tourism in the Third World. London: Routledge.

Nakai, T. (2002). Ecotourism on the local level: Attempts and problems on the Ogasawara Islands. Geographical Sciences, 57(3), 187-193.

Nand, S. (2013). The new economy: Utilizing creative, cultural and innovative industries for sustainable socioeconomic development in Fiji. Pacific Studies, 36(1/2), 94-104.

Nordin, S. (2003). Tourism clustering and innovation. Osterründ: European Tourism Research Institute, Mid-Sweden University.

Notzke, C. (2006). The stranger, the Native and the land: Perspectives on Indigenous tourism. North York, ON: Captus University Press.

Olsen, Kjell. (2008). The Maori of tourist brochures representing Indigenousness Journal of Tourism and Cultural Change, 6(3), 161-184.

OECD. (2001). Innovation and productivity in services. Paris: OECD.

Picard, D. (2007). Report for an EU funded regional development project: Regional Program for the sustainable development of coastal zones in Indian Ocean countries (ReCoMaP).

Power, D. (2010). The difference principle? Shaping competitive advantage in the cultural product industries. Journal of the Swedish Society for Anthropology and Geography, 145-158.

Power, D. \& Scott, A. (Eds.) (2004). Cultural industries and the production of culture. London: Routledge.

Prahalad, C. K. \& Ramaswarmy, V. (2004). The future of competition: Co-creating unique value with customers. Boston MA: Harvard Business Review Press.

Quitzow, R. (2013). Towards an integrated approach to promoting environmental innovation and national competitiveness. Innovation and Development, 3(2), 277-296.

Russell, A. \& Wallace, G. (2004). Editorial: Irresponsible ecotourism. Anthropology Today, 20(1), 1-2.

Schmid, H. (2009). Economy of fascination. Berlin: Gebrüder Borntraeger.

Schumpeter, J. (1975). Capitalism, socialism and democracy. New York: Harper. 
Shibazaki, S. (2005). Yakushima ni okeru jizokukanô na kankô no arikata ni tsuite [About options for sustainable tourism in Yakushima]. Nôgyô to Keizai 2005-6, 39-48.

SRI International. (2000). Tourism workforce development for cluster competitiveness. Retrieved from http://pdf.usaid.gov/pdf_docs/Pnacn125.pdf

Sofield, T. (2003). Empowerment for sustainable tourism development. Oxford: Pergamon.

Sorensen, A. \& Funck, C. (Eds.). (2007). Living cities in Japan. New York: Routledge.

Sternberg, R. (2009). Innovation. In D. Gregory, R. Johnson, G. Pratt, M. J. Watts \& S. Whatmore (Eds.), The dictionary of human geography. New York: Elsevier.

Stronza, A. (2005). Hosts and hosts: the anthropology of community-based ecotourism in the Peruvian Rainforest. National Association for the Practice of Anthropology Bulletin, 23, 170-190.

Tipa, G. \& Nelson, K. (2008). Introducing cultural opportunities: a framework for incorporating cultural perspectives in contemporary resource management. Journal of Environmental Policy and Planning, 10(4), 313-337.

Tokushû: "nyû tsûrizumu" no shijô kankiryoku (2008) [Special feature: the evocational market power of "new tourism"]. Rejâ Sangyô Shiryô, 11, 29-66.

Tukker, A. \& Tischner, U. (Eds.) (2006). New business for Old Europe: Product-service development, competitiveness and sustainability. Sheffield: Greenleaf Publishing.

Weidenfeld, A., Williams, A.M., and Butler, R.W. (2010). Knowledge transfer and innovation among attractions. Annals of Tourism Research, 37(3), 604-626.

Wurzel, R. K. W. (2008). European Union environmental policy and Natura 2000. In J. Keulartz \& G. Leistra (Eds.), Legitimacy in European nature conservation policy (pp. 259-282). Heidelberg: Springer Verlag.

Yea, S. (2002). On and off the ethnic tourism map in Southeast Asia: the case of Iban longhouse tourism, Sarawak, Malaysia. Tourism Geographies, 4(2), 173-194.

Zeppel, H. (2003). Sharing the country: ecotourism policy and indigenous peoples in Australia. In D. Fennell \& R.K. Dowling (eds) Ecotourism policy and planning (pp. 5576). Wallingford: CABI.

Zeppel, H. (2006). Indigenous ecotourism: Sustainable development and management. Wallingford: CABI. 